\title{
Spatial distribution of the toxic dinoflagellate Alexandrium tamarense in summer in the Okhotsk Sea off Hokkaido, Japan
}

\author{
Hiroshi Shimada ${ }^{1, *}$, Mayumi SaWAda ${ }^{1}$, TAKanori Kuribayashi ${ }^{1}$, Akifumi NaKata ${ }^{1}$, \\ AKIRA MIYAZONO $^{1} \&$ HIROKI ASAMI ${ }^{2}$ \\ ${ }^{1}$ Hokkaido Central Fisheries Experiment Station, 238, Hamanaka-cho, Yoichi, Hokkaido 046-8555, Japan \\ ${ }^{2}$ Hokkaido Wakkanai Fisheries Experiment Station, 4-5-15 Suehiro, Wakkanai, Hokkaido 097-0001, Japan
}

Received 18 July 2009; Accepted 2 November 2009

\begin{abstract}
To investigate the mechanisms influencing the spatial distribution of the toxic dinoflagellate Alexandrium tamarense in the Okhotsk Sea off Hokkaido, Japan, intensive field surveys were conducted at 34-37 stations in late July every year from in 2002-2007. Alexandrium tamarense occurred every year. However, the abundance of $A$. tamarense fluctuated year by year, with extremely low cell densities of $A$. tamarense in 2005 . High abundances of $A$. tamarense were found frequently in the oceanic area of the surface low-salinity water (LSW, salinity $\leq 32.5$ ) and the mixed water (MW). Low abundances were found along the coastal area of the Soya Warm Current (SWC, salinity $\geq 33.6$ ) and in the dichothermal water (DTW, temperature $\leq 2^{\circ} \mathrm{C}$ ) in the layer of oceanic areas deeper than $30 \mathrm{~m}$. The $\mathrm{PO}_{4}-\mathrm{P}$ concentration in each water mass was in the order DTW $>\mathrm{MW}>\mathrm{LSW}>\mathrm{SWC}$ and the lowest $\mathrm{PO}_{4}-\mathrm{P}$ concentration that occurred in the SWC is considered to be a potential limiting factor for the growth of $A$. tamarense. The reason for the low A. tamarense abundance in the DTW is considered to be the low water temperature and low light intensity. It is concluded that the water mass of LSW has favorable conditions for the growth of $A$. tamarense. The relative frequency of each water mass fluctuated every year and the results suggest that the frequency of occurrence of the LSW and MW is one of the most significant factors controlling the abundance of $A$. tamarense in the area.
\end{abstract}

Key words: Alexandrium tamarense, Hokkaido, Nutrients, Okhotsk Sea, Spatial distribution, Water mass

\section{Introduction}

Paralytic shellfish poisoning due to the toxic dinoflagellate Alexandrium tamarense (Lebour) Balech has caused extensive economic damage to the scallop aquaculture industry along the coast of Hokkaido in the Okhotsk Sea in summer every few years (Nishihama 1994, Shimada \& Miyazono 2005). Prediction of the poisoning is very important for controlling the fishing plan for scallops. Nishihama et al. (1993) and Nishihama (1994) reported that $A$. tamarense occurred in the surface of oceanic areas and the extension of oceanic surface waters to the coastal region might have a linkage with the occurrence of paralytic shellfish poisoning in the scallop culture grounds in the Okhotsk Sea. Similarly, Selina et al. (2006) reported that $A$. tamarense widely occurred around the coast of easternmost

*Corresponding author: Hiroshi Shimada; E-mail, shimadah@fishexp. pref.hokkaido.jp
Russia, including the Okhotsk Sea. Therefore the distribution of $A$. tamarense in the oceanic area off Hokkaido is very important information for evaluation of the risk of the occurrence of paralytic shellfish poisoning in summer. However, there is a paucity of information on the spatial distribution of $A$. tamarense in the complicated water mass structure in this region, because the water sampling of Nishihama et al. (1993) and Nishihama (1994) was conducted from only surface layers $(0$ and $5 \mathrm{~m})$.

Oceanographic structures of the Okhotsk Sea off Hokkaido are characterized by sea ice coverage in the winter season, and four distinct water masses in summer as follows (Aota 1975):

1. Soya Warm Current (SWC, salinity $\geq 33.6$ ): Warm current generally flowing along the coast of Hokkaido in the direction from Wakkanai to Abashiri, and originating from the Tsushima Warm Current

2. Surface low-salinity water (LSW, water temperature $\geq 2^{\circ} \mathrm{C}$, salinity $\geq 32.5$ ): Low salinity water mass in the sur- 


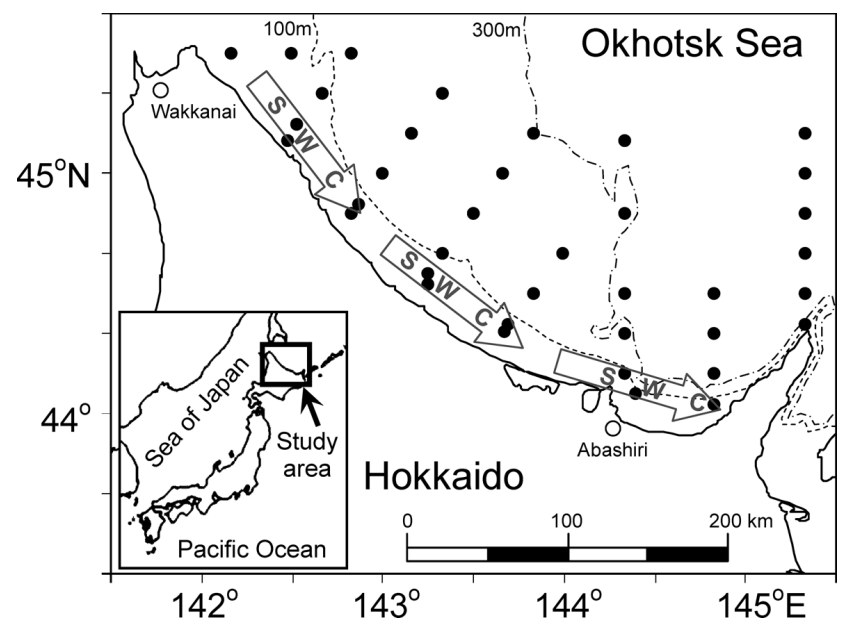

Fig. 1. Map showing 37 sampling stations (O) in the Okhotsk Sea off Hokkaido. Open arrows indicate schematic path of the Soya Warm Current.

face layer of the oceanic area of the Okhotsk Sea

3. Dichothermal water (DTW, water temperature $\leq 2^{\circ} \mathrm{C}$ ): Cold water mass under the LSW in the oceanic area

4. Mixed water (MW, water temperature $>2^{\circ} \mathrm{C}$, salinity $>$ 32.5 and $<33.6$ ): Water mass occurring from mixing among the above stated water masses (SWC, LSW and DTW)

Nishihama (1994) reported that $A$. tamarense occurred in the surface waters of the oceanic area in July 1989 at the same stations as in the present study. However, the spatial distribution of $A$. tamarense within the four water masses was not entirely elucidated. The aims of the present study are to clarify the relationship between spatial distribution and water mass structure and to get fundamental information for prediction of the paralytic shellfish toxin contamination of scallops along the coast of the Okhotsk Sea.

\section{Materials and Methods}

Map of the sampling stations and periods of surveys are shown in Fig. 1 and Table 1, respectively. Water samples were collected from each layer of $0,10,20,30$ and $40 \mathrm{~m}$ depth using Nansen bottles (1 L) at each station. $500 \mathrm{~mL}$ of each water sample was fixed with $2 \%$ formalin and concentrated to $1 \mathrm{~mL}$ by sedimentation for $6 \mathrm{~h}$. The cells numbers of Alexandrium tamarense in $0.1 \mathrm{~mL}$ subsamples were counted under an epifluorescence microscope (Nikon, XFEFD2) with UV excitation after calcofluor staining (Fritz \& Triemer 1985). Identification of A. tamarense was performed on the basis of morphology after Balech (1995). Water temperature and salinity were measured using CTD instruments (Seabird, SBE-911plus). Secchi disk transparencies were measured during daytime observations. $230 \mathrm{~mL}$ of each surface water $(0 \mathrm{~m})$ sample wase filtered through Whatman GF/F glass fiber filters. The filters were frozen at $-20^{\circ} \mathrm{C}$ in situ, and the chlorophyll $a$ concentra-
Table 1. Periods of surveys, number of sampling stations and research vessels.

\begin{tabular}{ccc}
\hline $\begin{array}{c}\text { Period of survey } \\
(\mathrm{m} / \mathrm{d} / \mathrm{y})\end{array}$ & Number of stations & Research vessel* \\
\hline July 22-25, 2002 & 37 & $\begin{array}{c}\text { Hokuyou Maru, } \\
\text { Oyashio Maru }\end{array}$ \\
July 24-26, 2003 & 37 & $\begin{array}{l}\text { Oyashio Maru } \\
\text { Oyashio Maru }\end{array}$ \\
July 23-25, 2004 & 35 & Oyashio Maru \\
July 21-23, 2005 & 37 & Oyashio Maru \\
July 25-27, 2006 & 34 & Oyashio Maru \\
July 25-27, 2007 & 35 & \\
\hline
\end{tabular}

* Hokuyou Maru: 214 ton, R/V of Hokkaido Wakkanai Fisheries Experiment Station

Oyashio Maru: 178 ton, R/V of Hokkaido Central Fisheries Experimet Station

tions were measured later using a fluorometer (Turner Design, 10-AU) after extraction by immersing the filter in $90 \%$ acetone for $6 \mathrm{~h}$ in the laboratory. Nutrient concentrations $\left(\mathrm{NO}_{3}-\mathrm{N}\right.$ and $\left.\mathrm{PO}_{4}-\mathrm{P}\right)$ in $30 \mathrm{~mL}$ subsamples from all the sampled depths in 2004-2007 were analyzed using an autoanalyzer (Bran+Luebbe, Autoanalyzer II).

\section{Results}

The spatial distributions of water temperature and water masses and cell densities of Alexandrium tamarense are shown in Fig. 2a, b. Overall trends of the distributions of the water masses were interpreted as follows. The SWC flowed along the coast of Hokkaido, the LSW occurred in the surface layer shallower than $10 \mathrm{~m}$ depth, the DTW was observed in the layer deeper than $30 \mathrm{~m}$ depth, and the MW was found among the water masses every year in 20022007. A tamarense was widely distributed in the oceanic area outside the SWC, varying with quantitative and spatial annual fluctuations while they were rarely sampled in 2005 . Blooms of $A$. tamarense $\left(\geq 10^{3}\right.$ cells $\left.\mathrm{L}^{-1}\right)$ appeared near the frontal area between the LSW and the SWC or the MW outside the SWC in 2004 and 2006. High abundances of $A$. tamarense $\left(\geq 10^{2}\right.$ cells $\left.\mathrm{L}^{-1}\right)$ occurred broadly in the LSW and the MW shallower than $20 \mathrm{~m}$, except for in 2005 . However, sporadic high abundances of $A$. tamarense were observed sometimes in the layer deeper than $30 \mathrm{~m}$ in 2002 , 2004 and 2007. Cell densities of $A$. tamarense, superimposed on temperature-salinity diagrams are shown in Fig. 3. Cell densities of $A$. tamarense in each water mass, and the water temperature and salinity values recorded for each bracket of $A$. tamarense abundance are given in Tables 2 and 3. As for the relationship between cell density of $A$. tamarense and water masses, the highest cell densities were found in the LSW and the second highest were in the MW. Low cell densities were found in the SWC and the DTW (Fig. 3). Concerning the vertical distribution, A. tamarense was frequently found in the surface layer shallower than 

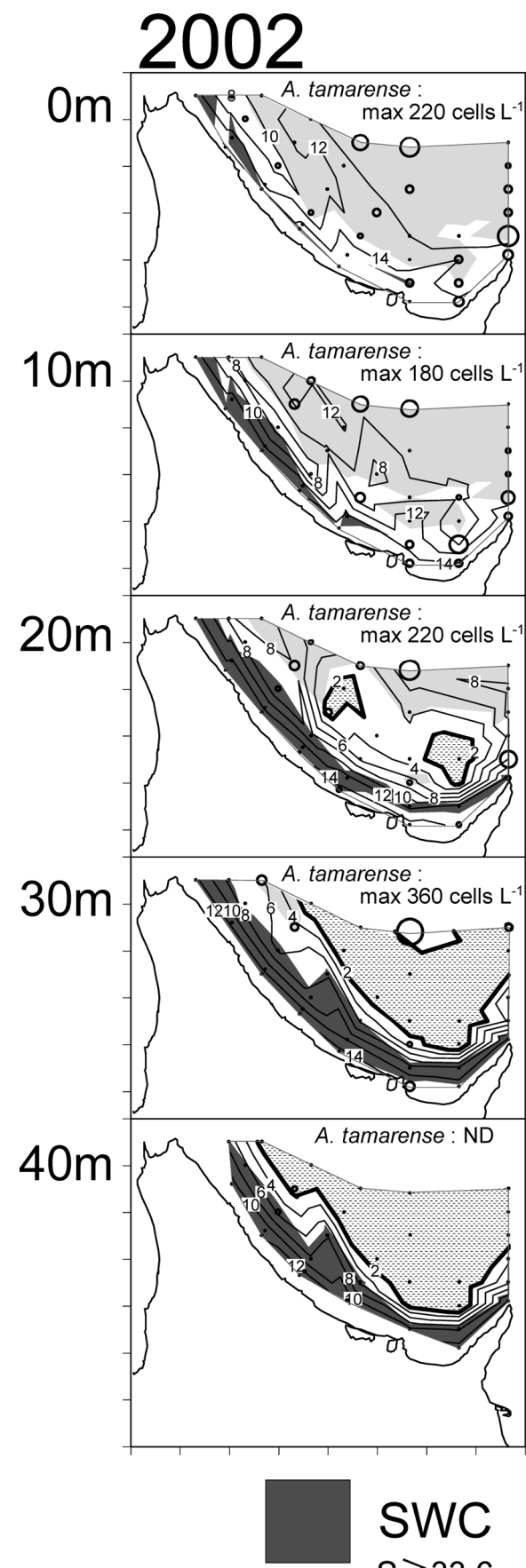

$S \geqq 33.6$

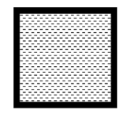

\section{DTW}

2003
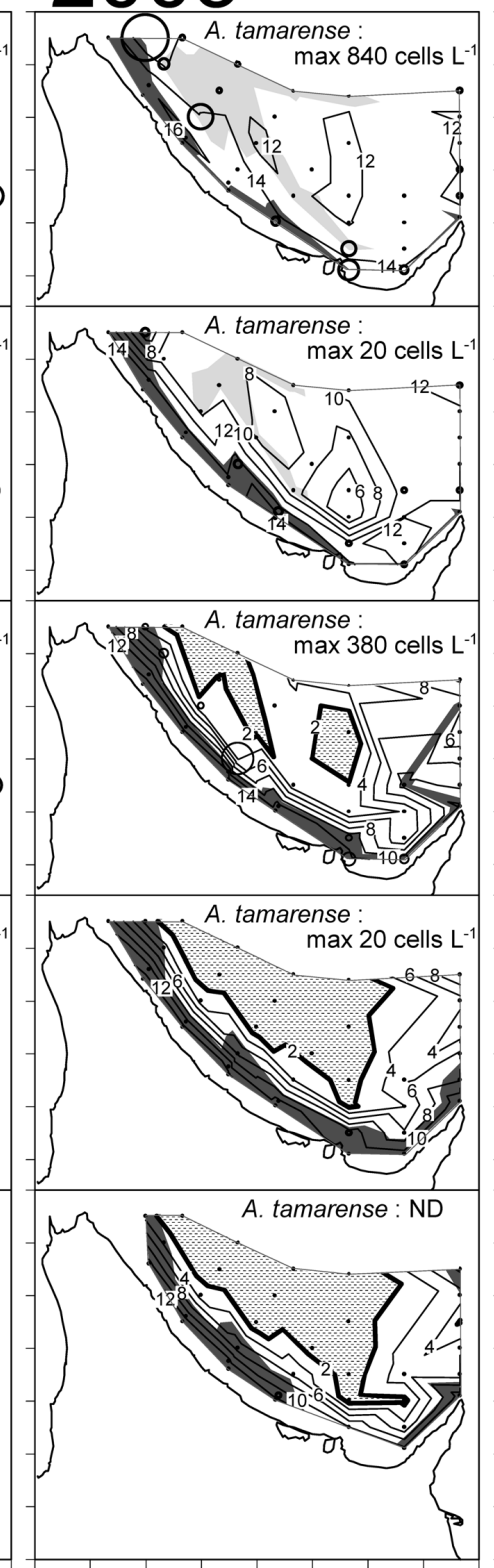

LSW

$\mathrm{s} \leqq 32.5$

MW

$\mathrm{T}>2^{\circ} \mathrm{C}$

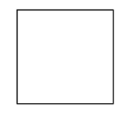

2004
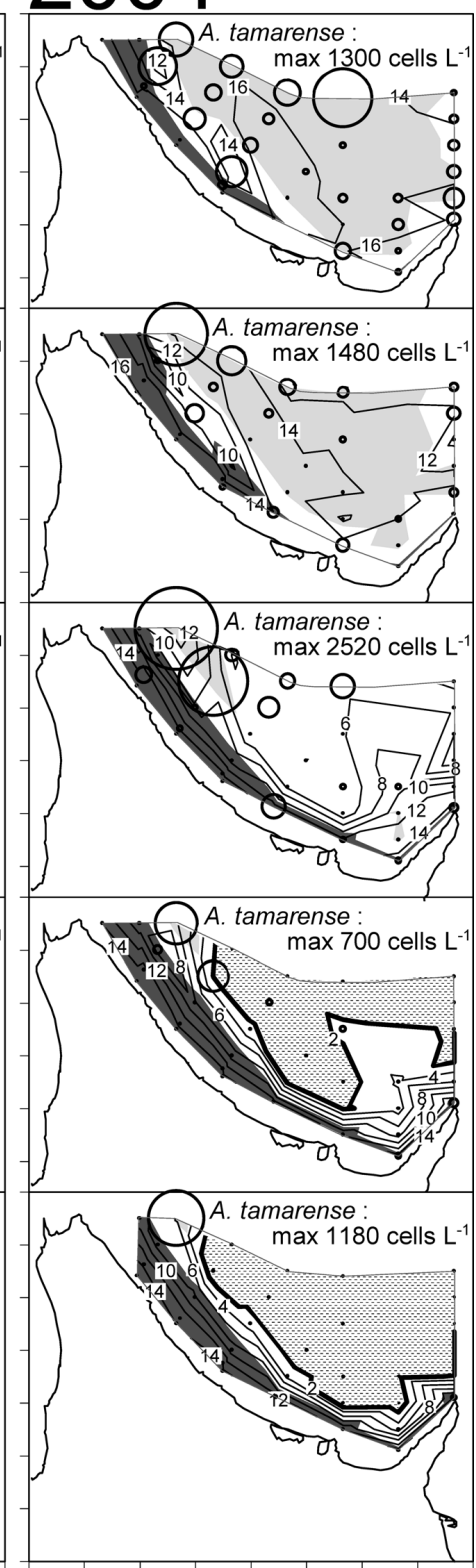

Diameter of bubbles:

A. tamarense (cells L ${ }^{-1}$ )

$S>32.5$ and $<33.6$

Fig. 2a. Spatial distribution of water temperature (contours), water masses (screentone) and cell density of Alexandrium tamarense (bubbles) in 2002-2004. Abbreviations of water masses are as follows. SWC: Soya Warm Current (salinity $\geq 33.6$ ). LSW: Surface low-salinity water ( salinity $\leq 32.5$ ). MW: Mixed water (water temperature $>2{ }^{\circ} \mathrm{C}$, salinity $>32.5$ and $<33.6$ ). DTW: Dichothermal water (water temperature $\leq 2^{\circ} \mathrm{C}$ ). 

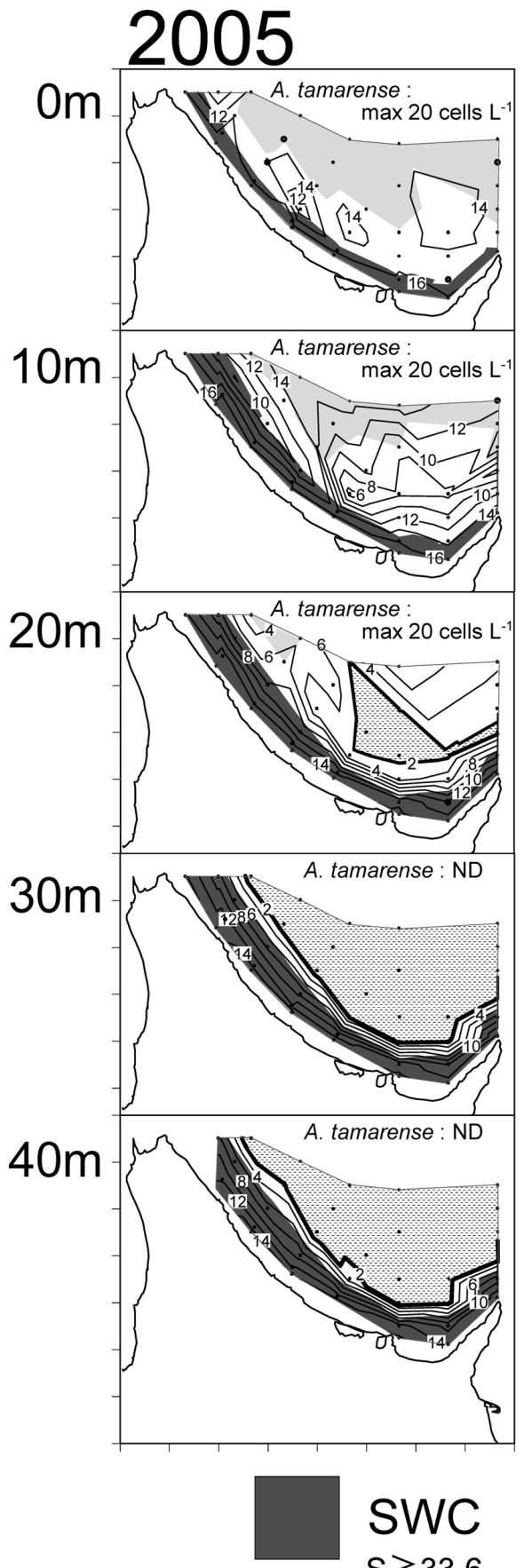

SWC

$S \geqq 33.6$

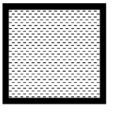

2006
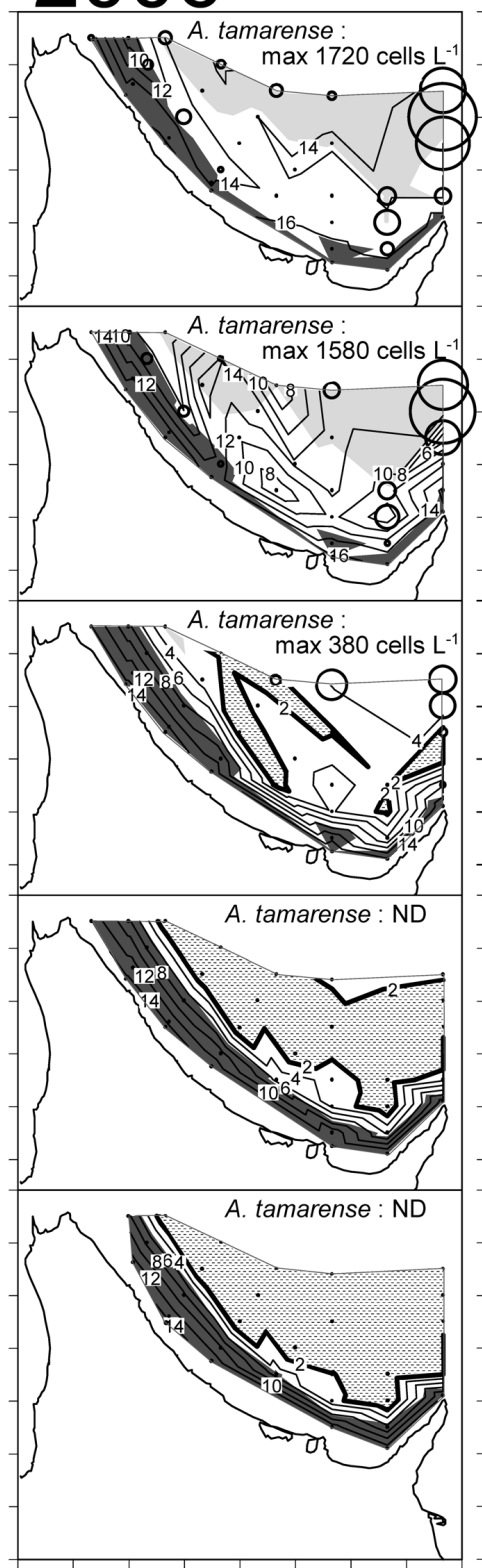

LSW

$\mathrm{S} \leqq 32.5$

MW

$\mathrm{T}>2^{\circ} \mathrm{C}$

$S>32.5$ and $<33.6$
2007

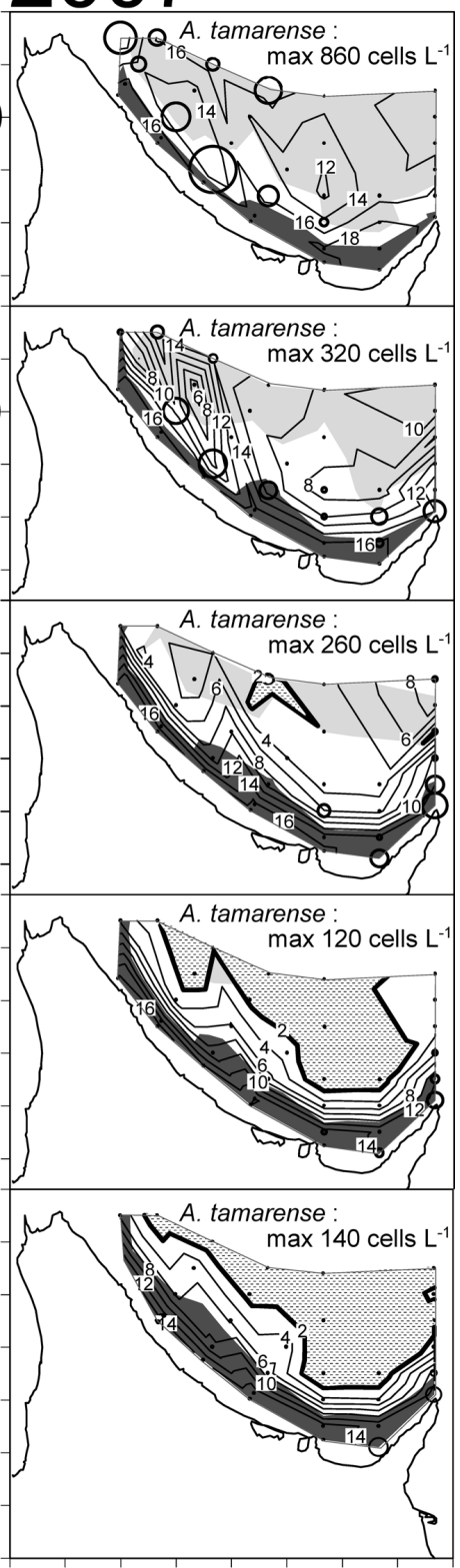

Diameter of bubbles:

A. tamarense (cells $\mathrm{L}^{-1}$ )

Fig. 2b. Spatial distribution of water temperature (contours), water masses (screentone) and cell density of Alexandrium tamarense (bubbles) in 2005-2007. 


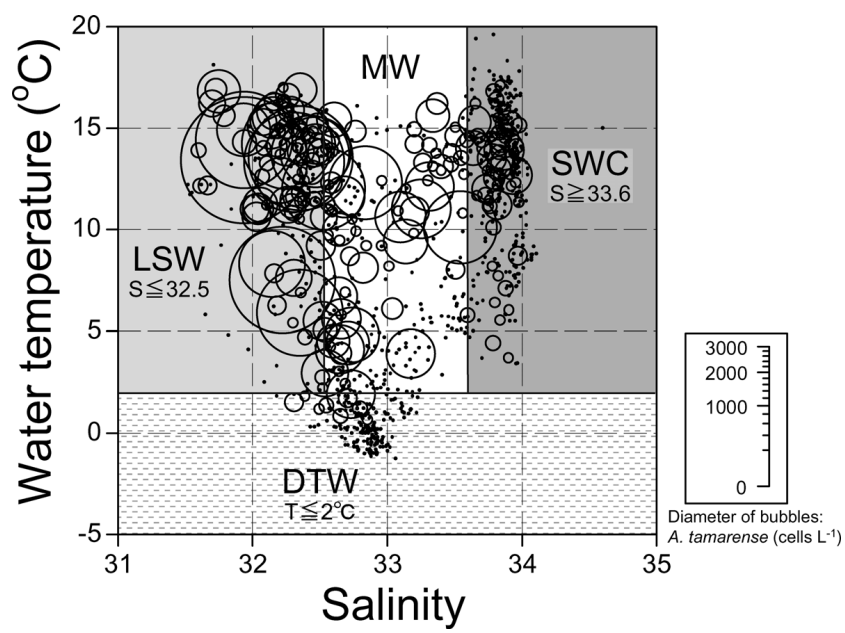

Fig. 3. Cell density of Alexandrium tamarense (bubbles) superimposed on the temperature-salinity diagram for data from 2002 2007. Screentones indicate the range of temperature and salinity of the four water masses.
Table 2. Cell density of Alexandrium tamarense in each water mass in 2002-2007. Abbreviations of water masses are as follows.

SWC: Soya Warm Current (salinity $\geq 33.6$ )

LSW: Surface low-salinity water (salinity $\leq 32.5$ )

MW: Mixed water (water temperature $>2{ }^{\circ} \mathrm{C}$, salinity $>32.5$ and $<33.6$ )

DTW: Dichothermal water (water temperature $\leq 2{ }^{\circ} \mathrm{C}$ )

\begin{tabular}{ccc}
\hline Water mass & $\begin{array}{c}\text { Number of } \\
\text { samples }\end{array}$ & $\begin{array}{c}\text { Cell density of } \\
\text { A. tamarense } \\
\text { (cells L }\end{array}$ \\
\hline SWC , mean \pm SD)
\end{tabular}

Table 3. Water temperature and salinity in each bracket of Alexandrium tamarense cell density in 2002-2007.

\begin{tabular}{cccc}
\hline $\begin{array}{c}\text { Range of } A \text {. tamarense } \\
\text { cell density } \\
\left(\text { cells L }{ }^{-1}\right)\end{array}$ & $\begin{array}{c}\text { Number of } \\
\text { samples }\end{array}$ & $\begin{array}{c}\text { Water temperature } \\
\left({ }^{\circ} \mathrm{C}, \text { mean } \pm \mathrm{SD}[\mathrm{min}-\max ]\right)\end{array}$ & $\begin{array}{c}\text { Salinity } \\
(\mathrm{mean} \pm \mathrm{SD}[\mathrm{min}-\mathrm{max}])\end{array}$ \\
\hline 0 & 730 & $8.1 \pm 5.8[-1.3-19.6]$ & $33.2 \pm 0.8[31.5-34.1]$ \\
$20-80$ & 137 & $11.1 \pm 4.3[0.7-17.0]$ & $32.9 \pm 0.7[31.6-34.0]$ \\
$100-980$ & 64 & $11.4 \pm 3.9[1.9-16.9]$ & $32.7 \pm 0.6[31.7-3.9]$ \\
$1000 \leq$ & 8 & $11.8 \pm 3.2[5.9-14.4]$ & $32.2 \pm 0.2[31.9-32.5]$ \\
\hline
\end{tabular}

$20 \mathrm{~m}$ depth, usually in the LSW and/or MW, but was rare in waters deeper than $30 \mathrm{~m}$ depth, where DTW prevailed (Fig. 2). Blooms of $A$. tamarense $\left(\geq 10^{3}\right.$ cells $\left.\mathrm{L}^{-1}\right)$ appeared at water temperatures of $5.9-14.4^{\circ} \mathrm{C}$ and salinities of 31.9 32.5 (Fig. 3, Table 3).

Depths of the euphotic layer were estimated from transparencies and defined as the layer shallower than the isolum of $1 \%$ of the light intensity at sea surface using the formula of Poole \& Atkins (1929); k=1.7/d (k: extinction coefficient, d: transparency) and the formula; $\mathrm{z}=-\log 0.01 / \mathrm{k}(\mathrm{z}$ : depth of the layer with $1 \%$ of the light intensity at the sea surface) and shown in Table 4. The euphotic layer depth was between 30 and $40 \mathrm{~m}$ in the LSW and MW, however the depth was deeper than $40 \mathrm{~m}$ in the SWC. Since the DTW existed below the LSW and MW, it could be estimated that the euphotic layer depth occurred between 30 and $40 \mathrm{~m}$ in the DTW, even without transparency observations. Therefore, the light intensity of the DTW deeper than $30 \mathrm{~m}$ was considered to be insufficient for photosynthesis.

Spatial distribution of nutrient concentrations and cell densities of $A$. tamarense in 2004-2007 are shown in Fig. $4 \mathrm{a}, \mathrm{b}$. Figure 5 shows the surface chlorophyll $a$ concentration and maximum cell density of $A$. tamarense at each sta-
Table 4. Estimated euphotic layer depth from measurements of transparency during daytime observations in 2002-2007.

\begin{tabular}{cccc}
\hline $\begin{array}{c}\text { Water mass of } \\
\text { 0 m layer }\end{array}$ & $\begin{array}{c}\text { Number of } \\
\text { observation }\end{array}$ & $\begin{array}{c}\text { Transparency } \\
(\mathrm{m}, \text { mean } \pm \text { SD) }\end{array}$ & $\begin{array}{c}\text { Euphotic layer } \\
\text { depth* } \\
\text { (m, mean } \pm \text { SD) }\end{array}$ \\
\hline SWC & 33 & $15.4 \pm 3.6$ & $41.7 \pm 9.8$ \\
LSW & 55 & $13.0 \pm 2.6$ & $35.3 \pm 6.9$ \\
MW & 36 & $11.1 \pm 2.6$ & $30.2 \pm 6.9$ \\
DTW & 0 & - & - \\
\hline
\end{tabular}

* Euphotic layer depth is estimated from transparency as the layer where light intensity has decreased to $1 \%$ of that at the sea surface, using the formula of Poole \& Atkins (1929): $\mathrm{k}=1.7 / \mathrm{d}$ (k: extinction coefficient, $\mathrm{d}$ : transparency) and the formula: $\mathrm{z}=-\log$ $0.01 / \mathrm{k}$ (z: depth of the layer with $1 \%$ of the light intensity at the sea surface).

tion in 2002-2007. Nutrient concentrations were relatively lower in the oceanic surface water of the LSW shallower than $10 \mathrm{~m}$ and the coastal water of the SWC in each of the four years. On the other hand, the concentrations were higher in the oceanic water of the DTW deeper than $30 \mathrm{~m}$ 


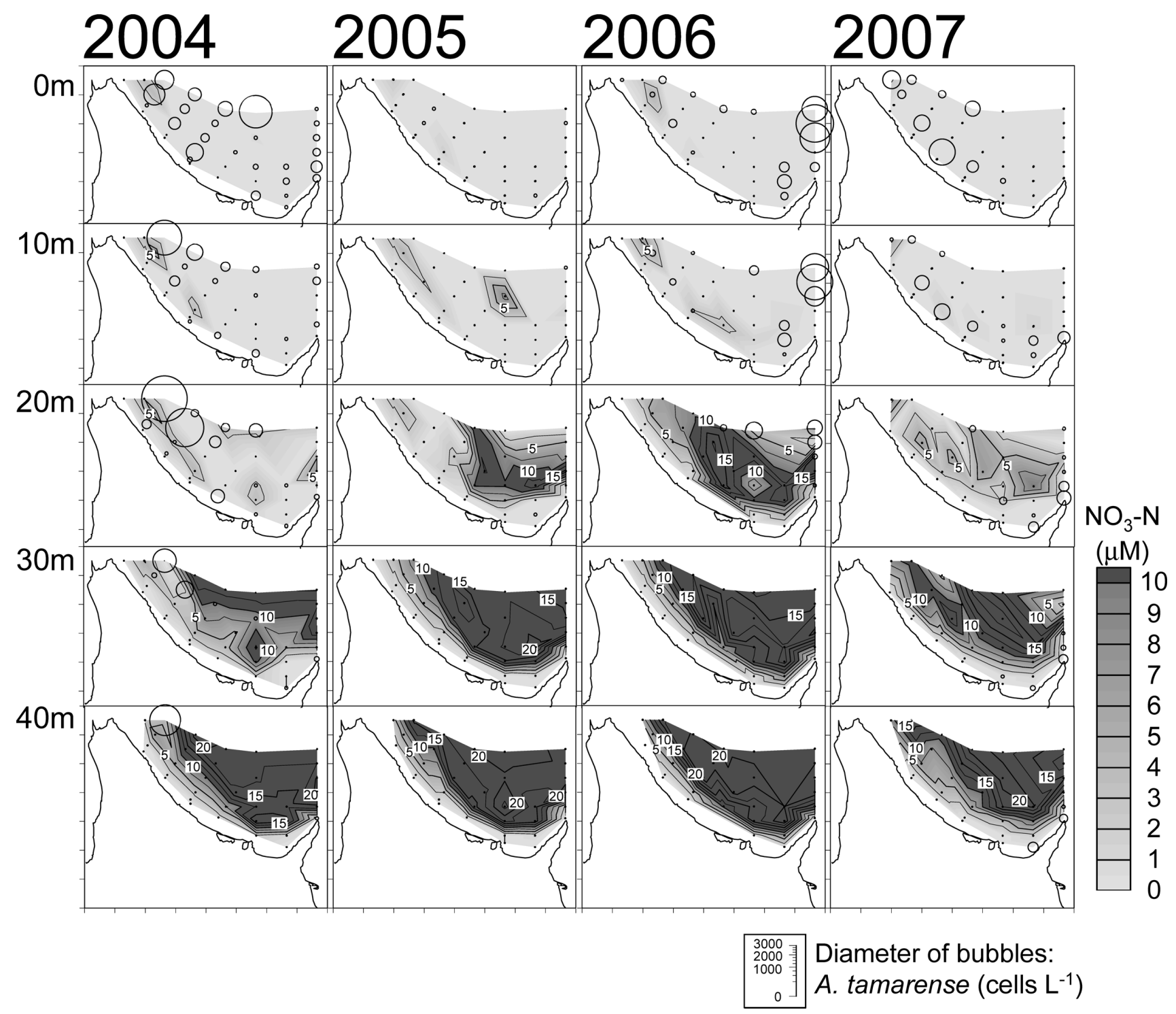

Fig. 4a. Spatial and vertical distribution of $\mathrm{NO}_{3}-\mathrm{N}$ concentration (contours) and cell density of Alexandrium tamarense (bubbles) in 2004-2007.

(see Fig. 2a, b). Surface chlorophyll $a$ concentrations were patchily high near the cold water belt along the frontal area just outside the SWC (see Fig. 2a, b). Blooms of $A$. tamarense $\left(\geq 10^{3}\right.$ cells $\left.\mathrm{L}^{-1}\right)$ were found off the patch of high chlorophyll $a$ concentration in 2004 and 2006. The diatoms Chaetoceros spp. and Thallassiosira spp. were the dominant species in the patch of high chlorophyll $a$ concentration.

Table 5 summarizes nutrient concentrations in each water mass. Regarding the relationship between cell density of $A$. tamarense and nutrient concentrations, the higher cell densities were not always found in waters with higher nutrient concentrations. In particular, low cell densities were found in the DTW with the highest nutrient levels but lowest water temperatures. On the other hand, in water with low nutrients, such as the LSW and the SWC, A. tamarense was frequently found in the LSW but rarely found in the SWC.
Comparing nutrient concentrations of the LSW and the $\mathrm{SWC}$, mean $\mathrm{NO}_{3}-\mathrm{N}$ concentration was lower in the LSW, and mean $\mathrm{PO}_{4}-\mathrm{P}$ concentration was lower in the SWC, respectively ( $t$-test, $p<0.01$ ).

\section{Discussion}

Based on the results of the present study, a schematic diagram is presented regarding the spatial distribution of water masses and Alexandrium tamarense in Fig. 6. It was clearly shown that $A$. tamarense occurred most frequently in the LSW followed by the MW in the oceanic areas, while A. tamarense was rarer in the SWC along the coastal area and in the DTW beneath the LSW and the MW. The present study revealed the detailed spatial distribution of $A$. tamarense in all of the water masses, surpassing the report on the distribution only from the surface layer by Nishi- 


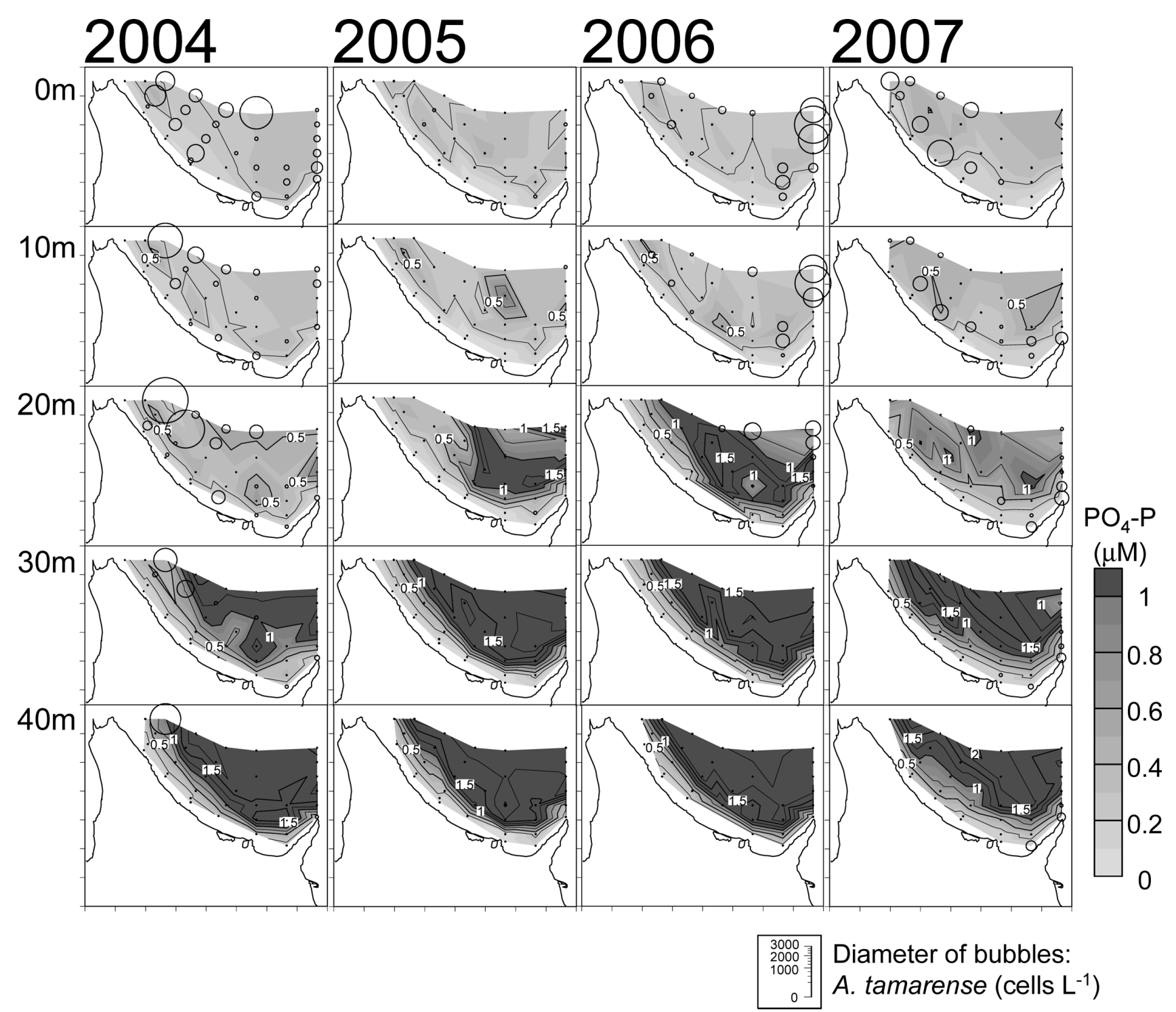

Fig. 4b. Spatial and vertical distribution of $\mathrm{PO}_{4}-\mathrm{P}$ concentration (contours) and cell density of Alexandrium tamarense (bubbles) in 2004-2007.

hama (1994). It has been reported in Funka Bay, southern Hokkaido, that the optimum water temperature for $A$. tamarense was $8-12^{\circ} \mathrm{C}$ (Nishihama 1982 ) and as $5-10^{\circ} \mathrm{C}$ (Shimada et al. 1996). In the present study, A. tamarense blooms were confirmed at temperatures of $5.9-14.4^{\circ} \mathrm{C}$ as is the case in Funka Bay.

Fukuyo (1982) reported that newly germinated cells of $A$. tamarense arising from cysts could not grow at the low water temperature of $5^{\circ} \mathrm{C}$. It can be suggested that $A$. tamarense can not increase in the DTW under the low water temperature regime (see Fig. 3) combined with the reduced light intensity as found in the present study. Tarutani (1999) suggested that in comparison with the dominant diatom species, $A$. tamarense was unable to increase to dominance because of their larger half-saturation constant for $\mathrm{PO}_{4}-\mathrm{P}$ uptake. Yamamoto \& Tarutani (1999) reported that the $\mathrm{PO}_{4}-\mathrm{P}$ concentration required for the maximum growth rate
(0.54 day $\left.^{-1}\right)$ of the $A$. tamarense Hiroshima Bay strain was estimated to be $0.12 \mu \mathrm{M}$ as estimated by a culture experiment. Shinada (2005) described that the $\mathrm{PO}_{4}-\mathrm{P}$ concentration of the SWC was lower than $0.12 \mu \mathrm{M}$ in most cases and insufficient to support growth of $A$. tamarense. In the present study, concentrations of $\mathrm{PO}_{4}-\mathrm{P}$ lower than $0.12 \mu \mathrm{M}$ occurred in $25 \%$ of all samples from the SWC. In summery, our results suggest that the lower $\mathrm{PO}_{4}-\mathrm{P}$ concentrations in the SWC, below those found in the LSW, are not always sufficient for growth of $A$. tamarense (see Table 5).

Why can $A$. tamarense increase in the LSW even though $\mathrm{NO}_{3}-\mathrm{N}$ concentrations are lower than in the other water masses? MacIntyre et al. (1997) suggested that $A$. tamarense sustains growth through nocturnal migrations to nutrient rich deeper layers for nitrogen uptake, based on a culture experiment using a laboratory water column $(2.1 \mathrm{~m}$ height). Lewis et al. (2006) reported that the mean swim- 


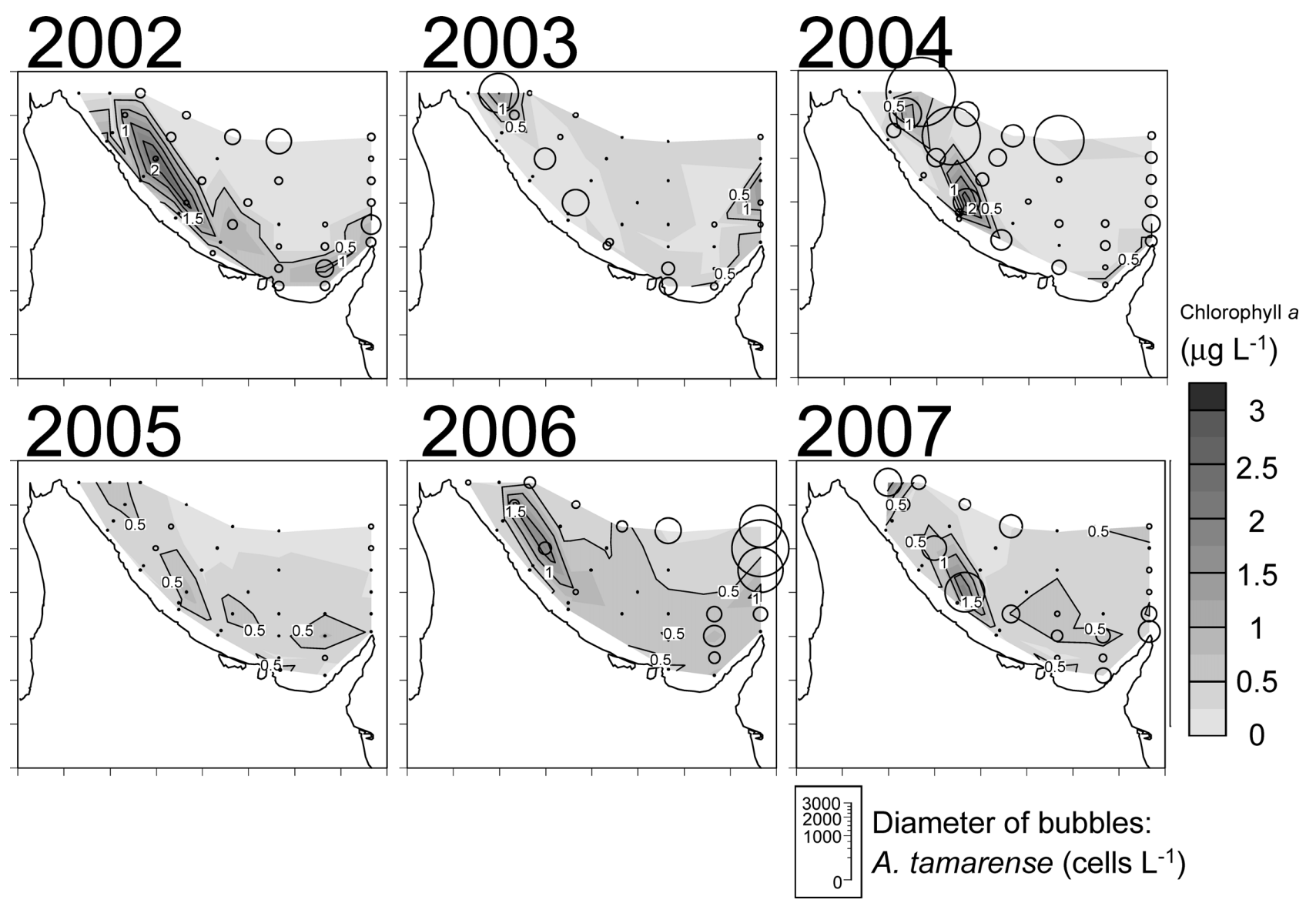

Fig. 5. Horizontal distribution of sea surface chlorophyll a concentration (contours) and maximum cell density of Alexandrium tamarense (bubbles) at each station in 2002-2007.

Table 5. Nutrient concentrations in water masses in 2004-2007.

\begin{tabular}{|c|c|c|c|}
\hline \multirow[b]{2}{*}{ Water mass } & \multirow[b]{2}{*}{$\begin{array}{l}\text { Number of } \\
\text { samples }\end{array}$} & \multicolumn{2}{|c|}{ Nutrient concentrations } \\
\hline & & $\begin{array}{c}\mathrm{NO}_{3}-\mathrm{N} \\
(\mu \mathrm{M}, \text { mean } \pm \mathrm{SD})\end{array}$ & $\begin{array}{c}\mathrm{PO}_{4}-\mathrm{P} \\
(\mu \mathrm{M}, \text { mean } \pm \mathrm{SD})\end{array}$ \\
\hline SWC & 225 & $1.52 \pm 2.41$ & $0.26 \pm 0.22$ \\
\hline LSW & 120 & $0.21 \pm 0.86$ & $0.35 \pm 0.15$ \\
\hline MW & 156 & $3.51 \pm 4.55$ & $0.59 \pm 0.37$ \\
\hline DTW & 125 & $15.79 \pm 4.53$ & $1.55 \pm 0.29$ \\
\hline
\end{tabular}

ming speed of $A$. tamarense was $108 \mathrm{~mm} \mathrm{~s}^{-1}(=3.89 \mathrm{~m}$ $\mathrm{h}^{-1}$ ) at a temperature of $12^{\circ} \mathrm{C}$ in a laboratory experiment. In the present study, it is thought that $A$. tamarense could increase in the LSW with low $\mathrm{NO}_{3}-\mathrm{N}$ concentrations through nocturnal migrations to the $\mathrm{MW}$ for $\mathrm{NO}_{3}-\mathrm{N}$ uptake. On the other hand, concerning nutrients, Ogata et al. (1996) found that $A$. tamarense can grow through utilization of organic nitrogen such as in yeast extract. It is also supposed that $A$. tamarense might utilize organic nitrogen in the LSW.

The present study found that the LSW is the most favorable water mass for the growth of $A$. tamarense. Figure 7 depicted annual fluctuations in the relative frequencies of each water mass and the annual average abundances of $A$. tamarense detected in samples at the same depth layers at the 34 stations and the 10 coastal stations collected in 2002-2007. It was found through analysis of the fluctuations at the 34 stations that the frequency of water preferred by $A$. tamarense (LSW+MW), was lowest in 2005 (see Fig. 7 above). This result suggests that water mass structure is a significant factor controlling the abundance of $A$. tamarense in the Okhotsk Sea. Regarding the abundances of $A$. tamarense in the coastal areas, which were suspected to be directly coupled with the occurrences of paralytic shellfish poisoning, it was found that the abundances of $A$. tamarense were low in 2005 and 2006 when the amounts LSW and the MW occurring were low (Fig. 7, lower figure), mirroring the results for oceanic areas.

It has been reported that large abundances of toxic Alexandrium spp. resting cysts can be found in bottom sediments on the continental shelf off Hokkaido and Sakhalin Island in the Okhotsk Sea (Orlova et al. 2004, Shimada \& Miyazono 2005). It was also reported that blooms $\left(\geq 10^{3}\right.$ cells $\mathrm{L}^{-1}$ ) of $A$. tamarense have occurred in Aniva Bay, southern Sakhalin Island (Selina et al. 2006). These reports indicate that $A$. tamarense originates by germination of cysts on the continental shelf in the area. Thus, one of the reasons why $A$. tamarense was frequently found in oceanic 


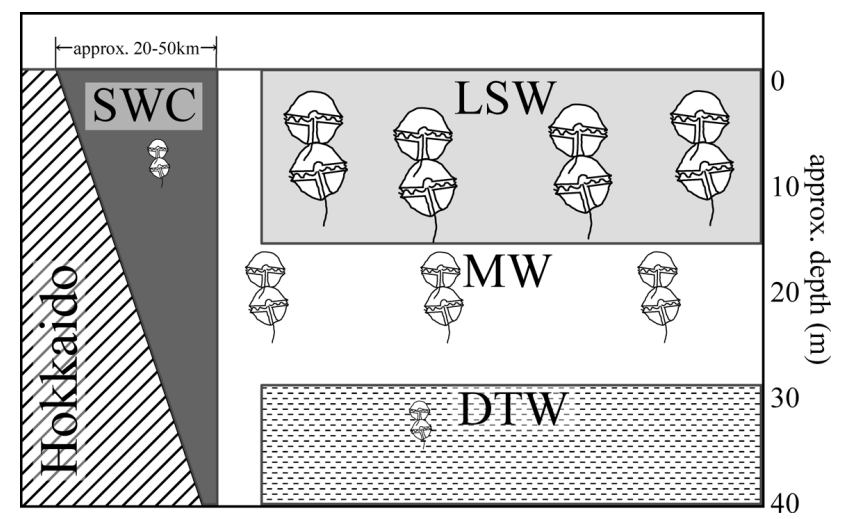

Fig. 6. Schematic diagram of spatial distribution of water masses and abundance of Alexandrium tamarense in vertical section. Cell size of icon indicates relative abundance.

areas of the LSW is that $A$. tamarense cells, originating from cysts, grow in the LSW water mass due to the optimum conditions for growth.

The blooms $\left(\geq 10^{3}\right.$ cells $\left.\mathrm{L}^{-1}\right)$ of $A$. tamarense tended to be found near the frontal areas outside the SWC in the present study. It has been reported that the formation of a cold water belt through upwelling can often be detected in the frontal areas in summer (Nakata et al. 1996, Ishizu et al. 2006), and that diatom blooms frequently occur through utilization of the richer nutrients in the upwelling water (Watanabe 1990). In the present study, the blooms of $A$. tamarense existed not within the frontal area, but rather near the frontal area where the diatom blooms were also found (Figs. 2a, b, 5). These results suggest that phototrophic dinoflagellates such as $A$. tamarense can not compete with diatoms generally because of disadvantages concerning their nutrient uptake abilities (Tarutani 1999, Shimada 2000, Miyazono \& Shimada 2000).

The SWC usually predominates along the coastal areas containing the culture grounds for scallops (Nishihama 1994). Paralytic shellfish poisoning might not have occurred if the SWC water mass had predominated continuously within the area, because the SWC contains only small numbers of $A$. tamarense. Our results suggest that paralytic shellfish poisoning occurs when the LSW containing $A$. tamanrense extends to the coastal area from the oceanic area due to physical processes (e.g. temporal weakening of the SWC). Nishihama et al. (1993) pointed out that the extension of LSW might have a strong linkage with the occurrence of paralytic shellfish poisoning in the culture grounds of scallops in the Okhotsk Sea, according to the observations of A. tamarense occurrences linked to salinity decreases in the surface water during July 1986. Therefore, it is important to elucidate the physical processes enabling the extension of LSW to the culturing grounds of scallop, and to establish a forecasting system for the occurrences of paralytic shellfish poisoning in the near future. Therefore we are now trying to elucidate the relationship between the extension of LSW contaminated with A. tamarense to the

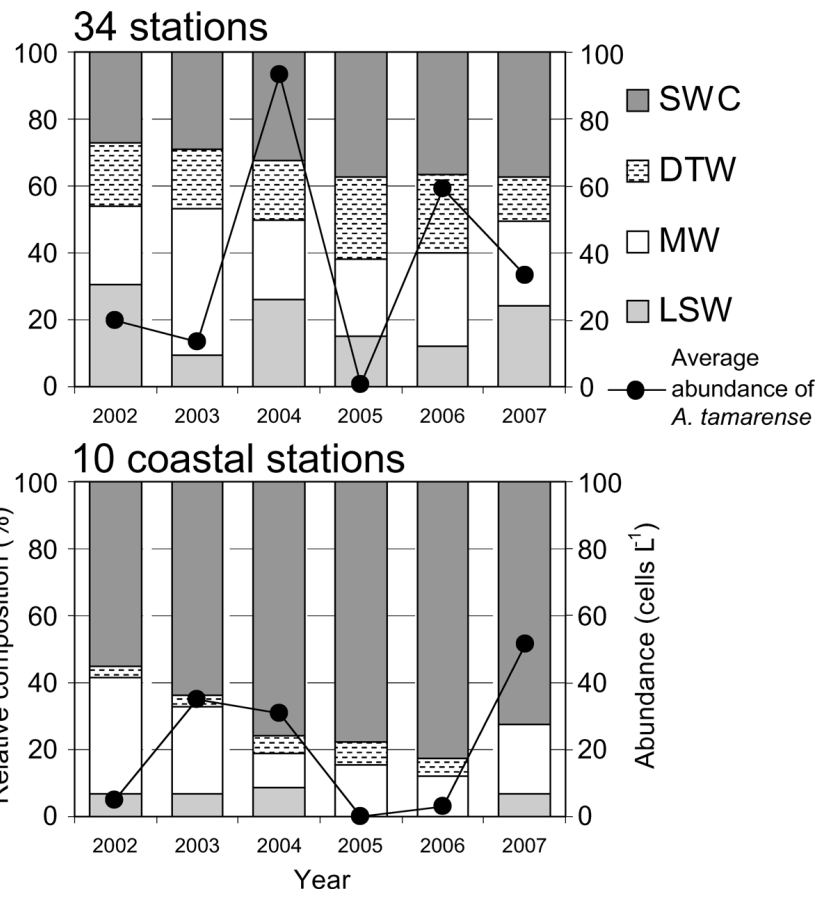

Fig. 7. Relative frequency of each water mass in the samples and annual average abundance of Alexandrium tamarense at the same depth layers at the 34 stations (above) and the 10 coastal stations (depth of bottom $<100 \mathrm{~m}$, below) in 2002-2007.

coastal area and the temporal weakening of the SWC.

\section{Acknowledgments}

We are deeply grateful to Mrs. T. A. Mogilnikova and Mrs. I. V. Motilkova of the Sakhalin Scientific Research Institute of Fisheries and Oceanography (SakhNIRO) for valuable information about the distribution of Alexandrium tamarense and the occurrence of paralytic shellfish poisoning along the coast of Sakhalin Island. We are grateful to the captains and crews of R/V Hokuyo Maru and Oyashio Maru for kindly helping with sampling. We also thank colleagues at the Hokkaido Fishery Experiment Station for their helpful comments.

\section{References}

Aota M (1975) Studies on the Soya Warm Current. Low Temperature Science A33: 151-172. (in Japanese with English summary)

Balech E (1995) The genus Alexandrium Halim (Dinoflagellata). Sherkin Island Marine Station, Shelkin Island, Co Cork, Ireland, $151 \mathrm{pp}$.

Fritz L, Triemer RE (1985) A rapid simple technique utilizing calcofluor white M2R for the visualization of dinoflagellate thecal plates. J Phycol 21(4): 662-664.

Fukuyo Y (1982) Taxonomical and ecological studies on Protogonyaulax occurring in Japanese coastal waters. PhD thesis, University of Tokyo, Tokyo, 220 pp. (in Japanese) 
Ishizu M, Kitade Y, Matsuyama M (2006) Formation mechanism of the cold-water Belt formed off the Soya Warm Current. J Oceanogr 62: 457-471.

Lewis NI, Xu W, Jericho SK, Kreuzer HJ, Jericho MH, Cembella AD (2006) Swimming speed of three species of Alexandrium (Dinophyceae) as determined by digital in-line holography. Phycologia 45(1): 61-70.

MacIntyre JG, Cullen JJ, Cembella AD (1997) Vertical migration, nutrition and toxicity in the dinoflagellate Alexandrium tamarense. Mar Ecol Prog Ser 148: 201-216.

Miyazono A, Shimada H (2000) Population dynamics of dinoflagellates after diatom bloom and environmental factors. Bull Coast Oceanogr 38(1): 29-38. (in Japanese with English abstract)

Nakata A, Tanaka I, Yagi H, Kantakov GA, Samatov D (1996) Origin of water in the cold water belt appearing offshore side of the Soya Warm Current near La Perouse Strait (the Soya Strait) In: Abstracts of the Fifth PICES Annual Meeting, Nanaimo, p. 42.

Nishihama Y (1982) Seasonal abundance of Protogonyaulax sp. causing paralytic shellfish poisoning in Funka Bay. In: Proceeding of North Pacific Aquaculture Symposium, Anchorage, pp. 319-327.

Nishihama Y (1994) Paralytic shellfish poisoning. In: Nishihama Y (ed) Scallop Fishery in the Okhotsk Sea Coast of Hokkaido. Hokkaido University Press, Sapporo, pp. 170-180. (in Japanese)

Nishihama, Y, Tada K, Miyazono A (1993) Occurrence of toxic dinoflagellate, Alexandrium tamarense, in Lake Saroma. Bull Plankton Soc Japan 39(2): 171-173.

Ogata T, Koike K, Nomura S, Kodama S (1996) Utilization of organic substances for growth and toxin production by Alexandrium tamarense. In: Yasumoto T, Oshima Y, Fukuyo Y (eds) Harmful and Toxic Algal Blooms. UNESCO, Sendai, pp. 343346.

Orlova TY, Morozova TV, Gribble KE, Kulis DM, Anderson DM
(2004) Dinoflagellate cysts in recent marine sediments from the east coast of Russia. Bot Mar 47: 184-201.

Poole HH, Atkins WRG (1929) Photo-electric measurement of submarine illumination throughout the year. J Mar Biol Ass UK 16: 297-324.

Selina MS, Konovalova GV, Morozova TV, Orlova TY (2006) Genus Alexandrium Halim, 1960 (Dinophyta) from the Pacific coast of Russia: species composition, distribution, and dynamics. Russ J Mar Biol 32(6): 321-332.

Shimada H (2000) Seasonal changes of phytoplankton species composition in Funka Bay. Bull Coast Oceanogr 38(1): 15-22. (in Japanese with English abstract)

Shimada H, Hayashi T, Mizushima T (1996) Spatial distribution of Alexandrium tamarense in Funka Bay, Southwestern Hokkaido, Japan. In: Yasumoto T, Oshima Y, Fukuyo Y (eds) Harmful and Toxic Algal Blooms. UNESCO, Sendai, pp. 219221.

Shimada H, Miyazono A (2005) Horizontal distribution of toxic Alexandrium spp. (Dinophyceae) resting cysts around Hokkaido, Japan. Plankton Biol Ecol 52(2): 76-84.

Shinada A (2005) Limiting factor for growth of Alexandrium tamarense in the coastal water, northeastern part of Hokkaido, Japan in summer. Sci Rep Hokkaido Fish Exp Stn 69: 117-121. (in Japanese with English abstract)

Tarutani K (1999) Ecophysiological studies on the population dynamics of toxic dinoflagellate Alexandrium tamarense. Bull Fish Environ Inland Sea 1: 63-96. (in Japanese with English abstract)

Watanabe T (1990) The Soya Strait, III. Chemistry. In: Kuniji H (ed) Coastal Oceanography of Japanese Islands, Supplementary Volume, pp. 438-445. (in Japanese)

Yamamoto T, Tarutani K (1999) Growth and phosphate uptake kinetics of the toxic dinoflagellate Alexandrium tamarense from Hiroshima Bay in the Seto Inland Sea, Japan. Phycol Res 47: $27-32$. 